\title{
Habitat constraints in epikarstic waters of an Iberian Peninsula cave system
}

\author{
A.I. Camacho ${ }^{1 *}$, A.G. Valdecasas ${ }^{1}$, J. Rodríguez ${ }^{1}$, S. Cuezva² ${ }^{2}$ J. Lario ${ }^{2,3}$, S. Sánchez-Moral ${ }^{2}$ \\ ${ }^{1}$ Dpt. of Biodiversity and Evolutionary Biology, Museo Nacional de Ciencias Naturales de Madrid (CSIC), C/ José Gutierrez Abascal 2, 28006 \\ Madrid, Spain. \\ 2 Dpt. of Geology, Museo Nacional de Ciencias Naturales de Madrid (CSIC), C/ José Gutierrez Abascal 2, 28006 Madrid, Spain. \\ ${ }^{3}$ Dpto. Ciencias Analíticas, Facultad de Ciencias, UNED, C/ Senda de Rey 9, 28040 Madrid, Spain.
}

\begin{abstract}
The epikarstic waters of a restricted sector of the Ojo Guareña cave (north Iberian Peninsula) were investigated to characterize the physico-chemical variation in an annual cycle, to improve the scarce knowledge of the aquatic cave fauna on the Iberian Peninsula, to look for distribution patterns of species per habitat along the annual cycle, and to search for the environmental basis (either physico- or hydro-geochemical) that could explain species distribution in the epikarst. The habitats studied included all puddles and gours present in the sector selected making a total of 51 chemical and 42 biological samples for the entire cycle. The waters show no appreciable contaminationand exhibit small chemical variations throughout the year which are patently affected by external weather conditions. The 53 taxa found belong to ten higher taxonomic groups (Oligochaeta, Turbellaria, Mollusca, Copepoda, Ostracoda, Isopoda, Bathynellacea, Tardigrada, Acarina and Cnidaria), and consist mainly of crustacea with a total of 27 species. Fourteen species were stygobionts (belonging to ten genera), nine of which are new to science and ten of which are endemic. Cave pools that appeared to be more stable in terms of water volume and mineralization, had a lower $\mathrm{pCO}_{2}$ and were carbonate oversaturated, harboured the greatest number of taxa. It is these pools that can maintain strictly cave dwelling species. Pools with lower levels of mineralization and greater water volume fluctuations had a lower diversity of fauna and in general lacked stygobiotic species.
\end{abstract}

Keywords : epikarstic water, cave, stygobite, chemistry, biodiversity.

\section{Introduction}

The epikarst, the upper most zone of karst, is "located within the vadose zone and is defined as the heterogeneous interface between unconsolidated material including soil, regolith, sediment, and vegetative debris, and solutionally altered carbonated rock that is partially saturated with water and capable of delaying or storing and locally rerouting vertical infiltration to the deeper regional phreatic zone of the underlying karst aquifer" (Jones et al. 2004). The epikarst is an important area for the transport of pollutants, an important water storage site and the habitat of perhaps the

\footnotetext{
* Corresponding author :

E-mail: mcnac22@mncn.csic.es
}

most diverse assemblage of obligate inhabitants of subterranean waters (stygobionts) in the subterranean world (Jones 2003). It is its extraordinarily complex and heterogeneous structure that makes the epikarst the home of a wide array of animals, often rivalling in diversity the rest of the karst aquifer (Pipan \& Brancelj 2004). Despite being known to spelobiologists for decades, the epikarst has been poorly studied (Sket et al. 2004, Brancelj \& Culver 2004). This paucity in research can be attributed to the difficulty of studying these habitats, as the epikarst is only accessible indirectly: by sampling the drip, the drip gours and puddles (pools) and the trickles of percolation water (Pipan 2005).

Work on the epikarst in the last few years has focused mainly on the diversity of copepods, both in North America (Pipan 2004, Reid 2004, Pipan \& Culver

Article available at http://www.limnology-journal.org or http://dx.doi.org/10.1051/limn/2006009 
2005) and Europe (Slovenia, especially) (Brancelj 2002, Brancelj \& Pipan 2004, Pipan \& Brancelj 2001, 2003, 2004a, 2004b, Pipan 2003, 2005, Pipan et al. 2006) owing to the fact that these crustaceans have the largest and most diversified populations in the karst (Pipan \& Brancelj 2004a). Due to the lack of direct sampling, the studies are difficult to design (Pipan \& Culver 2005). More general studies include those on faunistic information in particular cave systems of North America, Europe and Australia (Malard \& Gibert 1997, Culver et al. 1994, Culver \& Sket 2000, Pesce et al. 2004, Jefferson et al. 2004), global studies of karstic areas (Proudlove 2001, Culver \& Holsinger 1992, Gibert et al. 1994, Sket 1999, Culver et al. 2000, Know \& Culver 2001, Graenning et al. 2003, Schneider \& Culver 2004, Apostolov \& Pandourski 2004), studies of whole regions (Culver et al. 2003, Moldovan 2002, Humphreys 2002), countries (Culver et al. 2000, Culver et al. 2004, Kniss 2004, Negrea \& Boitan 2001) and even the world (Deharveng \& Bedos 2000, Gibert et Deharveng 2002, Sket et al. 2004a) with data on the epikarst and other sectors of the karstic system (sources, subterranean rivers, etc.).

There are two basic approaches to the study of epikarstic biodiversity dictated by the difficulty of access to the cave environment. One is extensive sampling of the cave system with no special consideration for temporal changes and the other places special emphasis on temporal changes the latter, but on a restricted sector of caves. The present work is a contribution to the knowledge of the environmental and faunistic heterogeneity of the epikarstic aquatic habitats, over a period of one year at four subsectors in the Ojo the GuareÒa Cave, in the northern region of the Iberian Peninsula. This cave system is $100 \mathrm{~km}$ in total length and the sector studied represents about $3 \%$ of the total length.

\section{Material and Methods}

\section{Site description}

Ojo Guareña cave system (GEE 1986), one of the longest caves in Europe, is distributed over five overlapping levels comprised of passages up to $10 \mathrm{~m}$ high and $20 \mathrm{~m}$ wide with three main entrances and several other minor cavities. Over $100 \mathrm{~km}$ of galleries, developed in Cretaceous limestone, have been surveyed (Puch 1998). No previous study on the microclimate of this cave has been published. The Ojo Guareña karst contains numerous pools of standing water that are refilled by drip water or by streams after intense rainfall.
For the purpose of our study we separated the pools into two types: gours and puddles. A gour is formed by a vadose speleothem deposit developing along the margin of a pool. Puddles consist of standing water that accumulates in small hollows on clay cavern floors; they are associated with flowing streams. In the aquatic cave microhabitats, it is very difficult to establish a regular sampling strategy over a particular period of time: water disappears from some of the habitats at certain times and at other habitats the amount of water is so small that it is not biologically appropriate to take a sample as this would eradicate a local population.

The present study was performed in a sector some 3 $\mathrm{km}$ in length, with four subsectors and ten sampling points. Names refer to local designations (subsector 1, "Museo de Cera", OG-01; subsector 2, "Gours Hojas", OG-07, OG-08, OG-10 and OG-15; subsector 3, "Italianos", OG-02 and OG-12; subsector 4, "Galeria Principal", OG-9, OG-14 and OG-16) along the main path leading inward from the "Palomera" entrance. A one month sampling interval for chemical analysis and a three month interval for biological analysis was planned in the ten cave locations (Table 1) with different aquatic habitats (from August 2002 to September 2003) (Fig.1). The temporary nature of some of these habitats hindered the sampling over the entire annual cycle. At the end, only 6 locations (OG-07, OG-08, OG-09, OG-10, OG-12 and OG-14) - those where water remained present during the entire period ranging from 22-11-2002 to 27-09-2003 - were selected for complete chemical analysis and for shared analysis of chemistry and fauna. Samples taken at other dates from the ten habitats have been included in the analysis when available for the period between 2002 and the end of 2003, and this is indicated in the text.

The total number of biological samples collected was 42 and for chemical analysis, 51 samples were collected. There were 20 samples for the joint chemical and faunistic analyses, and 39 chemical samples for the six locations in the annual cycle.

\section{Samples}

Water samples from puddles and gours were collected in pre-washed, sterilized $200 \mathrm{ml}$ bottles. Temperature and dissolved oxygen were measured using a Yellow Spring YSI 55 apparatus, $\mathrm{pH}$ was measured with a Hanna HI 9025 meter, and conductivity was determined with a HI 9033 conductivity meter (all in situ). Additional water samples were collected in $125 \mathrm{ml}$ containers (previously washed with distilled water) and kept below $4{ }^{\circ} \mathrm{C}$ until analysis in the laboratories of 


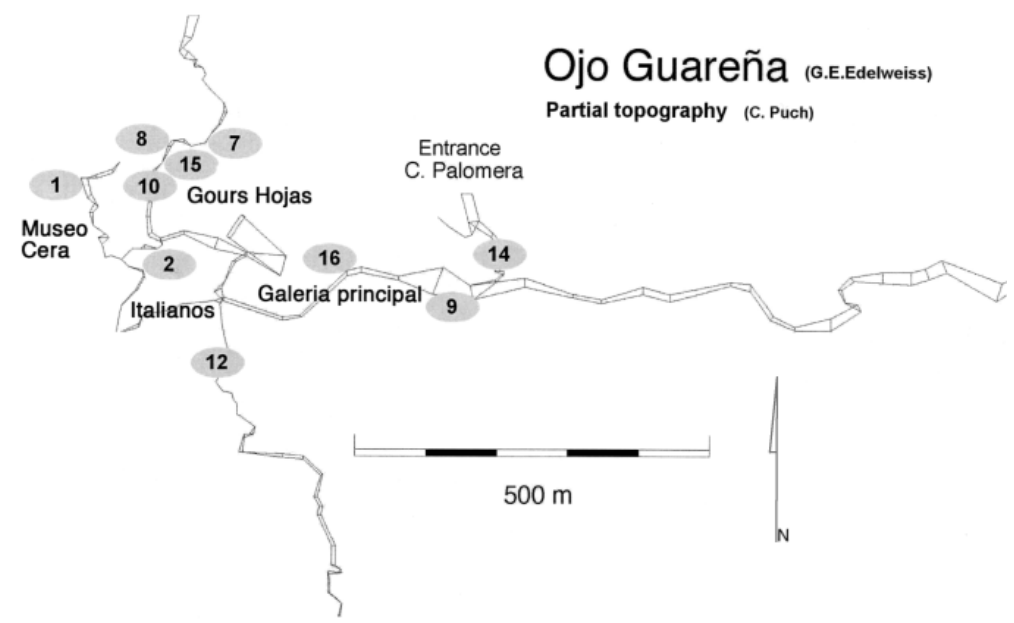

Fig. 1. Topography and sampling locations in the restricted sector in Ojo Guareña Cave (Burgos, Spain).

Table 1. Description of the sampling points and environmental variables in the Ojo Guareña Cave (Burgos, Spain). Habitat type: gour and puddle; Substrate: R= rock, RS= rock/sand, MS= mud/sand, SS= stones/sand, RSS= rock/sand/stones and MSS= mud/sand/stones; type of bottom: $\mathrm{C}=$ consolidated and $\mathrm{NC}=$ non-consolidated; water character: $\mathrm{T}=$ temporary water $(*$ high permanence of water) and $\mathrm{P}=$ permanent water; depth: $\mathrm{H}=$ high $(>40 \mathrm{~cm}), \mathrm{M}=$ medium $(30-40 \mathrm{~cm})$ and $\mathrm{L}=$ low. $(<20 \mathrm{~cm})$ Sampling sites are ordered along a longitudinal gradient from the main entrance to the cave. In bold= the six locations with data for annual cycle.

\begin{tabular}{|c|c|c|c|c|c|c|c|}
\hline Sample point & Habitat & Substrate & Bottom & Water character & Depth & Biological samples & Chemical samples \\
\hline OG-1 & Gour & RS & C & $T$ & L & 2 & 3 \\
\hline OG-2 & Gour & RS & C & $\mathrm{T}$ & L & 3 & 3 \\
\hline OG-07 & Puddle & MS & NC & T & L & 4 & 5 \\
\hline OG-08 & Puddle & SS & NC & $T^{*}$ & L & 6 & 6 \\
\hline OG-10 & Puddle & MS & NC & T & M & 5 & 6 \\
\hline OG-15 & Gour & RS & C & $\mathrm{T}$ & M & 3 & 4 \\
\hline OG-12 & Puddle & $\mathrm{R}$ & C & $\mathrm{P}$ & M & 4 & 6 \\
\hline OG-16 & Puddle & RSS & C & $\mathrm{T}$ & L & 3 & 2 \\
\hline OG-09 & Gour & RS & C & $\mathrm{P}$ & $\mathrm{H}$ & 6 & 8 \\
\hline OG-14 & Puddle & MSS & $\mathrm{NC}$ & P & M & 6 & 8 \\
\hline
\end{tabular}

the National Museum of Natural Sciences (MNCN), Madrid, Spain. In the laboratory, all water samples were analysed by ionic capillary electrophoresis using a QUANTA 4000 capillary electrophoresis instrument (Waters, Milford, MA, USA) equipped with a positive power supply and a variable-wavelength UV detection system. All chemical and standard solutions were prepared using deionised water (18 MV) produced from a Milli-Q water purification system.

Qualitative biological sampling was performed by removing the substrate and filtering with a100 $\mu \mathrm{m}$ mesh hand net. All samples were fixed in the field with $4 \%$ formalin and preserved in $70 \%$ alcohol one week later. Sample sorting was performed at our laboratory in Madrid using a stereoscopic microscope.

\section{Statistical analyses}

The calculations required to determine the mineral saturation indices and $\mathrm{pCO} 2$ values in the water samples were performed using the PHRQPITZ v0.2 computer program (1990) (a modification of the original version by Plummer et al. 1988). Field $\mathrm{pH}$ and temperature measurements were taken into account in the calculation of solubility and saturation state.

Multivariate analyses (using the PRIMER v5 package; Clarke \& Gorley 2001) were performed on the data from the 39 water samples taken at different dates from the six cave locations mentioned above (Table 2). All environmental variables except $\mathrm{pH}$ and temperature were $\log$ transformed $\mathrm{y}_{\mathrm{t}}=\log (0.1+\mathrm{y})$, where $\mathrm{yt}$ is the transformed value. Fauna data were analysed on a presence/absence basis. The clustering of environmen- 
Table 2. Chemical analyses of water and on-site measurements. Concentrations are expressed in mg/L. (EC= Electric Conductivity, $\mu \mathrm{S} / \mathrm{cm}$ ). *Dates with biological samples. A=30/08/2002, summer; $B=22 / 11 / 2002$, autumn; $C=25 / 01 / 2003$, winter; D=08/03/2003, winter; $E=07 / 06 / 2003$, spring; $F=27 / 09 / 2003$, summer; $G=04 / 04 / 2003$ spring and $H=10 / 05 / 2003$, spring. Form.= Formiate.

\begin{tabular}{|c|c|c|c|c|c|c|c|c|c|c|c|c|c|c|c|}
\hline \multirow{6}{*}{$\begin{array}{l}\text { Point } \\
\text { OG-07 }\end{array}$} & \multirow{3}{*}{$\begin{array}{l}\text { Date } \\
C \\
* D\end{array}$} & \multicolumn{2}{|c|}{$\mathrm{T}\left({ }^{\circ} \mathrm{C}\right) \mathrm{pH}$} & \multicolumn{2}{|c|}{$\mathrm{O}_{2}(\%) \mathrm{EC}$} & \multirow{2}{*}{$\begin{array}{l}\mathrm{Cl}^{=} \\
2.8\end{array}$} & \multicolumn{2}{|c|}{$\mathrm{SO}_{4}{ }^{=} \mathrm{NO}_{3}^{-}$} & \multicolumn{2}{|c|}{$\mathrm{HCO}_{3}{ }^{2} \mathrm{~F}^{=}$} & \multicolumn{3}{|c|}{ Form. $\mathrm{Ca}^{++} \mathrm{Mg}^{++}$} & \multirow{2}{*}{$\begin{array}{l}\mathrm{K}^{+} \\
0\end{array}$} & \multirow{2}{*}{$\begin{array}{l}\mathrm{Na}^{+} \\
1.6\end{array}$} \\
\hline & & 8.4 & 7.50 & 65.5 & 328 & & 4.3 & 0.3 & 215 & 0 & 0 & 70 & 1.7 & & \\
\hline & & 8.2 & 7.80 & 65.3 & 165 & 5.5 & 4.7 & 1.07 & 308 & 0 & 0 & 97.9 & 1.6 & 1.6 & 2.4 \\
\hline & $G$ & 8.6 & 7.70 & 77.7 & 197 & 4.4 & 3.7 & 1.45 & 89 & 0 & 0 & 26.7 & 1.1 & 1.3 & 2.6 \\
\hline & $\mathrm{H}$ & 8.6 & 7.70 & 86.2 & 259 & 4.4 & 4 & 2 & 115 & 0 & 0 & 36.7 & 1.5 & 1.4 & 2.8 \\
\hline & ${ }^{\star} \mathrm{E}$ & 8.6 & 7.53 & 73.3 & 296 & 5 & 8 & 2.3 & 174 & 0 & 0.01 & 50.2 & 2.1 & 1.5 & 3.1 \\
\hline \multirow[t]{6}{*}{ OG-08 } & ${ }^{*} \mathrm{~B}$ & 10.2 & 7.70 & 82 & 528 & 5.8 & 5.5 & 1.8 & 370 & 0 & 0 & 119 & 1.96 & 0 & 2.3 \\
\hline & $\mathrm{c}$ & 10.1 & 7.60 & 84.7 & 508 & 3.7 & 4.5 & 0.4 & 300 & 0 & 0 & 952. & 1 & 0 & 1.5 \\
\hline & ${ }^{*} \mathrm{D}$ & 10 & 7.80 & 57.3 & 475 & 4.2 & 4 & 0 & 69 & 0 & 0 & 21.3 & 1 & 0.94 & 3.0 \\
\hline & G & 9.9 & 7.60 & 75.7 & 443 & 4.66 & 4.71 & 1.45 & 250 & 0 & 0 & 74.8 & 1.6 & 0.23 & 3.0 \\
\hline & $\mathrm{H}$ & 10.1 & 7.94 & 79.5 & 477 & 3.6 & 5.3 & 0.93 & 280 & 0 & 0 & 83.2 & 1.79 & 1.43 & 3.2 \\
\hline & ${ }^{\star} \mathrm{E}$ & 9.3 & 7.54 & 89.4 & 386 & 4.9 & 5.1 & 1.2 & 245 & 0 & 0.02 & 68.2 & 1.83 & 0.57 & 3.0 \\
\hline \multirow[t]{8}{*}{ OG-09 } & ${ }^{*} \mathrm{~A}$ & 7.8 & 7.50 & 76 & 312 & 5.1 & 5.1 & 2.8 & 206 & 0 & 0 & 65.7 & 2.1 & 0.17 & 1.5 \\
\hline & ${ }^{*} \mathrm{~B}$ & 8.1 & 7.6 & 79.3 & 294 & 25.7 & 4.1 & 16.1 & 283 & 0.0 & 0 & 109.7 & 2.7 & & 1.6 \\
\hline & C & 7.1 & 7.90 & 78 & 370 & 3.9 & 3.6 & 3.7 & 250 & 0 & 0 & 85.4 & 2.1 & 0 & 1.9 \\
\hline & ${ }^{*} D$ & 7.6 & 8.00 & 78.4 & 369 & 4.1 & 4 & 0 & 113 & 0 & 0 & 38.1 & 1.1 & 0.26 & 2.1 \\
\hline & $G$ & 6.8 & 7.90 & 81.8 & 284 & 6.94 & 5.58 & 3.46 & 160 & 0 & 0 & 50.4 & 1.72 & 0.42 & 2.5 \\
\hline & $\mathrm{H}$ & 7.8 & 7.77 & 72.2 & 326 & 5.38 & 4.91 & 2.92 & 155 & 0 & 0 & 50.4 & 1.72 & 0.22 & 2.3 \\
\hline & ${ }^{*} \mathrm{E}$ & 7.3 & 7.67 & 87 & 303 & 6 & 6 & 3.1 & 165 & 0 & 0.0 & 48.1 & 1.84 & 0.46 & 2.5 \\
\hline & $\mathrm{F}$ & 8.0 & 7.16 & 80 & 313 & 4.83 & 5.28 & 2.43 & 189 & 0 & 0 & 52.90 & 1.91 & 2.04 & 2.0 \\
\hline \multirow[t]{6}{*}{ OG-10 } & ${ }^{*} \mathrm{~B}$ & 9.3 & 8.1 & 79.8 & 479 & 5.2 & 5.2 & 1.6 & 360 & 0 & 0 & 102 & 2.72 & 0 & 5 \\
\hline & ${ }^{*} \mathrm{C}$ & 3.6 & 7.5 & 81.2 & 392 & 3.6 & 4.2 & 0.6 & 68 & 0 & 0 & 37 & 2.18 & 0 & 1.9 \\
\hline & D & 8.3 & 7.8 & 67.8 & 418 & 6.1 & 5 & 1. & 15 & 0 & 0 & 65.7 & 1.72 & 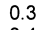 & \\
\hline & G & 8.1 & 7.90 & 72.8 & 316 & 5.44 & 4.72 & 0.62 & 180 & 0 & 0 & 53.9 & 1.48 & 0.4 & 3.0 \\
\hline & $\mathrm{H}$ & 8.6 & 8.02 & 77.6 & 405 & 3.77 & 4.44 & 0.99 & 240 & 0 & 0 & 68 & 1.76 & 0.3 & 3.1 \\
\hline & ${ }^{*} \mathrm{E}$ & 8.7 & 7.55 & 87.1 & 327 & 4.2 & 5.3 & 1.2 & 180 & 0 & 0.04 & 54.6 & 1.72 & 0.41 & 3.0 \\
\hline \multirow[t]{6}{*}{ OG-12 } & ${ }^{*} \mathrm{C}$ & 4.7 & 6.6 & 86 & 127 & 1. & 3 & 0 & & 0 & 0 & 23.5 & 1.25 & 1.4 & 2 \\
\hline & ${ }^{*} D$ & 5.5 & 7.0 & 65.2 & 150 & 5.09 & 4.04 & 2.7 & 205 & 0 & 0 & 72.5 & 1.78 & 1.99 & 2.6 \\
\hline & $G$ & 5.2 & 7.5 & 80.9 & 146 & 4.38 & 4.23 & 1.28 & 63 & 0 & 0 & 19.5 & 1.18 & & 8 \\
\hline & $\mathrm{H}$ & 6.4 & 7.61 & 83.8 & 162 & 4.13 & 4.29 & 1.32 & 63 & 0 & 0 & 22.1 & 1.29 & 2.09 & 2.4 \\
\hline & ${ }^{*} \mathrm{E}$ & 6.2 & 7.5 & 87.5 & 164 & 4.3 & 7.1 & 1.4 & 80 & 0 & 0.05 & 24.4 & 1.55 & 1.85 & 2.8 \\
\hline & $\mathrm{F}$ & 7.0 & 6.90 & 80.8 & 313 & 5.30 & 6.20 & 2.19 & 180 & 0 & 0 & 49.50 & 2.72 & 1.92 & 2.8 \\
\hline \multirow{8}{*}{ OG-14 } & ${ }^{*} \mathrm{~A}$ & $8 . C$ & 7.85 & 61 & 217 & 5.7 & 5 & 1. & 13 & 0 & 0 & 40 & 2 & 0. & 1.7 \\
\hline & ${ }^{*} \mathrm{~B}$ & 8.4 & 8.00 & 79.5 & 456 & 4.6 & 6.6 & 0.82 & 340 & 0. & 0 & & 3.75 & & 8 \\
\hline & C & 8.4 & 7.70 & 80.8 & 521 & 3.5 & 5. & 0 & 31 & 0 & 0 & & 3.2 & 0 & 1.9 \\
\hline & ${ }^{*} D$ & 9. & 8.1 & 78.2 & 588 & 4.7 & 6.3 & 0 & 296 & 0 & 0 & 90.4 & 2.8 & 1.08 & 2.7 \\
\hline & $G$ & 7.7 & 8.00 & 76.6 & 416 & 5 & 7. & 0.5 & 240 & 0.08 & 0 & 72.8 & 2.73 & 0.83 & 3.1 \\
\hline & $\mathrm{H}$ & 9.4 & 8.20 & 73.5 & 470 & 4.6 & 20.1 & 1.52 & 265 & 0 & 0 & 86.3 & 2.98 & 0.76 & 2.8 \\
\hline & ${ }^{*} \mathrm{E}$ & 8.4 & 8.07 & 75 & 388 & 4.8 & 7.3 & 0.6 & 20 & 0 & 0.0 & 65.9 & 2.77 & 0.55 & 2 \\
\hline & ${ }^{*} \mathrm{~F}$ & 8.4 & 7.74 & 61 & 243 & 6.10 & 6.30 & 1.27 & 137 & 0 & 0 & 41.40 & 1.81 & 0.39 & 2.6 \\
\hline
\end{tabular}

tal variables was performed by "averaging” (UPGMA) from an Euclidean distance matrix. Principal component analysis (PCA) of the environmental data was carried out using the correlation matrix. Non-metric multidimensional scaling (NMDS) ordinations were obtained from the distance and similarity matrices mentioned above. The non-parametric analysis of similarities test (ANOSIM, Clarke \& Green, 1988) was used to determine whether the differential distribution of samples was significantly different from a random ordination. This test is frequently used in ecological research (Chapman \& Underwood 1999). The null hypothesis assumes that there are no differences between the samples in the different habitats. This is tested by calculating an index " $\mathrm{R}$ " which contrasts between-site and within-site rank similarities.

$R=\frac{\left(\bar{r}_{B}-\bar{r}_{W}\right)}{\frac{1}{2} M}$ where:

$\overline{r_{B}}$ is the average rank of all similarities for all pairs of samples between sites,

$\overline{r_{W}}$ is the average of all rank similarities among samples within sites, $M=n(n-1) / 2$, where $n$ is the total number of samples considered.

The closer the value of $\mathrm{R}$ to 1 , the more similar the samples belonging to a particular site are than they are to samples from a different site. This index was recalculated using permutations. Significance was determined by comparing the observed $\mathrm{R}$ value to its permutation distribution. Chemical and faunal data were analysed using the BIOENV subroutine of the PRIMER package. This program compares the fauna similarity matrix (20x20) with the distance environmental matrix $(20 \times 20)$ and selects the best explanatory variables maximizing the rank correlation between them. A more detailed explanation of all these analyses can be found in the work of Clarke \& Warwick (2001). 


\section{Results}

\section{Physico-chemical analysis}

On-site measurements and laboratory analyses of the 39 water samples from the six pools ( 1 gour and 5 puddles) show that all samples were from unpolluted waters of the $\mathrm{Ca}^{2+}-\mathrm{HCO}^{-}$type, with limited variation but varying concentrations of total dissolved mineral species (Table 2). There is a strong correlation ( $\mathrm{r}=$ 0.9575 ) between calcium and bicarbonate and the concentration of total dissolved chemical species, indicated by the specific conductance, with temperature (0.5937), as expected (Fig. 2.1 and 2.2).

Solute concentration in waters varied significantly depending on: 1) external climatic conditions 2) pool water depth, 3) rate of infiltrating water, 4) flow routes to the cave and 5) nature of bottom pool. The

\section{1}

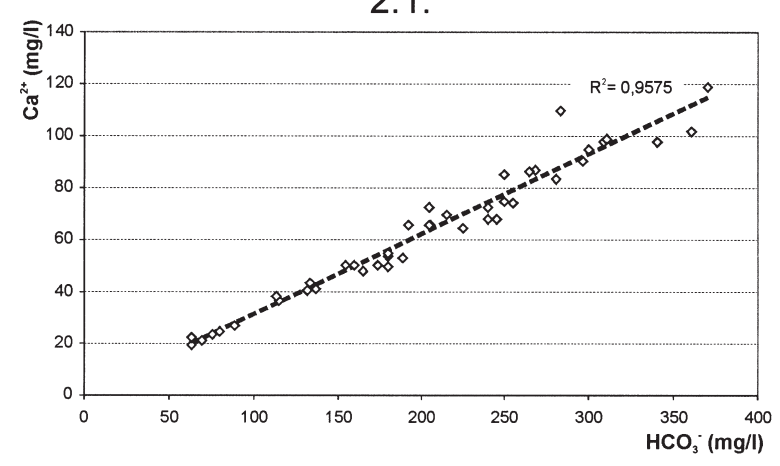

2.2.

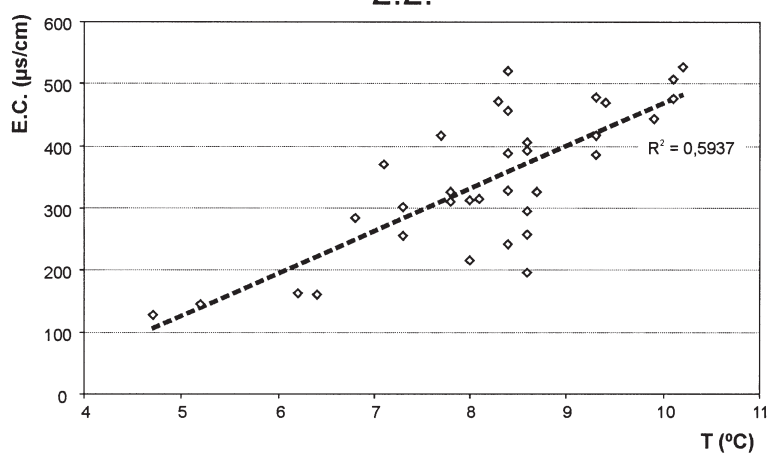

Fig. 2. Calcium versus bicarbonate concentration (Fig.2.1) and the electric conductivity and temperature (Fig.2.2) relationship of 6 sites in Ojo Guareña Cave (Spain) based on samples collected from $30 / 08 / 2002$ to $10 / 05 / 2003$. pools/puddles with nonconsolidated bottoms (OG-8, OG-10, OG-14) had higher concentrations of dissolved solids than those with rock/speleothem bottoms. This is due to the particulate nature of the sediments, and the subsequently higher water/rock ratio. The water of pool OG-12 showed the least mineralization, while that of OG- 8 was the most concentrated over the year. Pool OG-9 was the least affected by changes in concentration as a result of its depth. Seasonal variation in OG-9 was similar to that in OG-14, with the highest concentrations during winter owing to the increase in carbonate solubility with low temperature. In September 2003 an abrupt reduction in the concentration of OG-14 was seen, probably related to a storm some time before sampling (this pool was the closest to the entrance of the cave). OG-7 showed the typical trend of small gours/puddles, with a reduction in its concentration after a rainfall event in April and a progressive increase in concentration during the summer. The concentration of chemical species in these pools is increased by the slow evaporation that occurs whenever the relative humidity falls slightly below the saturation point.

With respect to the mean $\mathrm{pCO}_{2}$ values (Fig. 3), the highest were detected in OG-12 $\left(10^{-2.41} \mathrm{bar}\right)$, a relatively isolated pool. The lowest values were recorded in OG-14 (10-2.72 bar), again reflecting its proximity to the main entrance. Although the average chemical composition of the analysed waters experienced minor variations over the year, the $\mathrm{CO}_{2}$ concentration was significantly affected by seasonal changes, with a similar pattern at all sampling points (Fig. 3). The highest $\mathrm{pCO}_{2}$ values corresponded to dry periods (winter/summer) due to the scarcity of water in the soil. The effect of dryness and rainfall can be seen in the samples collected in September 2003 from pools OG-9 and OG12 , and to a lesser extent from OG-14. The $\mathrm{CO}_{2}$ produced in the soil by biological activity is dissolved by occasional rainwater. When this filters into the cave, partial degassing occurs until equilibrium is reached with the $\mathrm{CO}_{2}$ pressure of the cave atmosphere. Consequently, the $\mathrm{pCO}_{2}$ of any standing water depends directly on that of the cave atmosphere, which in turn depends on both external meteorological variables and the geometry of the cavity (Sanchez-Moral et al., 2006). Geochemistry and the saturation state of dripwaters on time periods vary from sub-seasonal to multi-year (Fairchild et al., 2006).

With respect to saturation indices (Table 3), the pools/puddles with non-consolidated bottoms (OG-8, OG-10, OG-14) were regularly oversaturated or close to equilibrium; OG-14 had the highest and most stable mean degree of oversaturation. On the other hand, OG- 

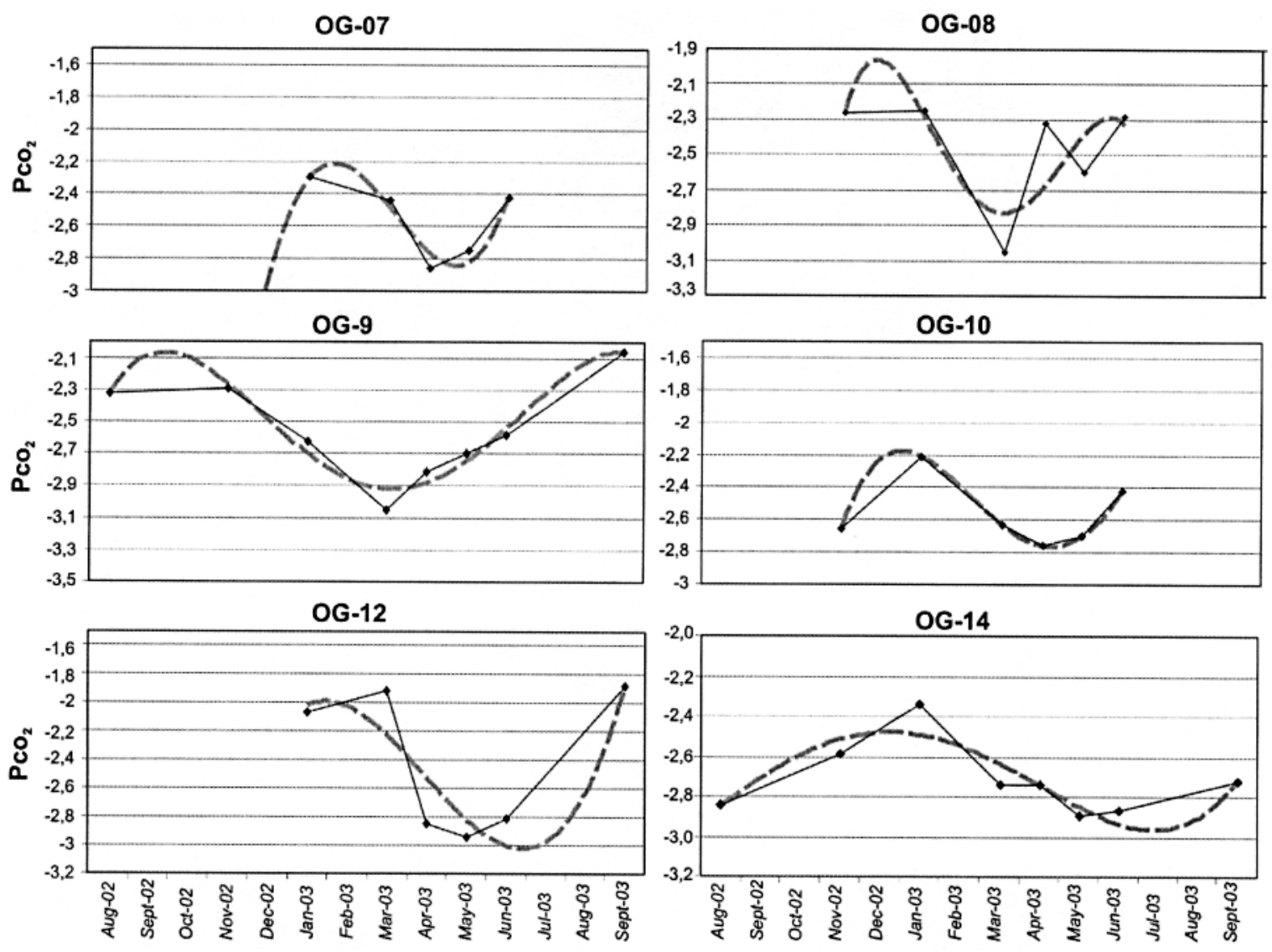

Fig. 3. Variations of the partial pressure of $\mathrm{CO}_{2}\left(\mathrm{pCO}_{2}\right)$ of the water samples collected in six pools during an annual cycle from August 2002 to September 2003.

7 and especially OG-12 were commonly undersaturated. Due to its large volume of water, OG-9 showed a stable state close to equilibrium. All the samples collected in the winter of 2002-2003 show pronounced oversaturation despite their high pCO2 values. This is indicative of a dry, cool period with scarce water recharge and slow evaporation.

A PCA was performed using the data from the 39 water samples (Table 2) to determine the overall pattern of chemical variation (Table 4). Three axes explained more than half of the variance in the chemical data. Sulphate, nitrite, magnesium and sodium have the highest scores on the first axis, $\mathrm{pH}$ and Formiate on the second axis, and temperature on the third.

One of the aims of the study was to determine whether the chemistry of the different habitats followed a similar pattern in terms of sampling date, type of habitat, location in the cave and the temporary or perma- nent nature of the present water in pools. An exploratory cluster analysis based on the Euclidean distance matrix and UPGMA grouping algorithm showed that the habitats tend to group by season rather than location, spring and winter being the seasons with greater influence (Fig. 4). An ordination analysis (NMDS) shows that only the sampling date segregates data that called for significance testing (Fig. 5). Consequently, ANOSIM was used to test whether the grouping by sampling dates was significant. Table 5 includes those significantly different dates at $\mathrm{p} \leq 0.05$.

The water chemistry of the sampled habitats is clearly different at different times. Samples taken in spring ( $\mathrm{E}$ and $\mathrm{H})$ were clearly different from those taken in summer (A and $\mathrm{F}$ ) and at the end of autumn and in winter (B and $\mathrm{C})$. This may be due to summer and winter droughts which result in low water levels in the small pools, while at the end of the spring, thawing and rain replenish the pools with varying rates and rhythms. 
Table 3. Partial pressure of $\mathrm{CO}_{2}$ (expressed as $\log \mathrm{pCO}_{2}$ ) and calcium carbonate saturation index of sampled water. Arag $=$ Aragonite, Calc $=$ Calcite.

\begin{tabular}{|c|c|c|c|c|c|}
\hline Sampling point & Date & $\mathrm{T}\left({ }^{\circ} \mathrm{C}\right)$ & $\log \mathrm{pCO} 2$ & Arag. & Calc. \\
\hline \multirow[t]{5}{*}{ OG-07 } & $25 / 01 / 03 \mathrm{C}$ & 8.4 & -2.3 & -0.19 & -0.03 \\
\hline & $08 / 03 / 03 * D$ & 8.2 & -2.44 & 0.4 & 0.55 \\
\hline & $04 / 04 / 03 \mathrm{G}$ & 8.6 & -2.86 & -0.71 & -0.56 \\
\hline & $10 / 05 / 03 \mathrm{H}$ & 8.6 & -2.75 & -0.48 & -0.33 \\
\hline & $07 / 06 / 03 *{ }^{*} \mathrm{E}$ & 8.6 & -2.42 & -0.37 & -0.21 \\
\hline mean & & 8.48 & -2.55 & -0.27 & -0.12 \\
\hline \multirow[t]{6}{*}{ OG-08 } & $22 / 11 / 02$ *B & 10.2 & -2.26 & 0.47 & 0.63 \\
\hline & $25 / 01 / 03$ C 1 & 0.1 & -2.25 & 0.2 & 0.35 \\
\hline & $08 / 03 / 03 * D$ & 10 & -3.05 & -0.78 & -0.63 \\
\hline & $04 / 04 / 03 \mathrm{G}$ & 9.9 & -2.32 & 0.03 & 0.19 \\
\hline & 10/05/03 H 1 & 0.1 & -2.6 & 0.47 & 0.62 \\
\hline & $07 / 06 / 03{ }^{*} \mathrm{E}$ & 9.3 & -2.28 & -0.09 & 0.07 \\
\hline mean & & 9.93 & -2.46 & 0.05 & 0.21 \\
\hline \multirow[t]{8}{*}{ OG-09 } & $30 / 08 / 02$ *A & 7.8 & -2.32 & -0.24 & -0.08 \\
\hline & $22 / 11 / 02 * B$ & 8.1 & -2.29 & 0.19 & 0.34 \\
\hline & $25 / 01 / 03 \mathrm{C}$ & 7.1 & -2.63 & 0.34 & 0.5 \\
\hline & 08/03/03 *D & 7.6 & -3.05 & -0.18 & -0.02 \\
\hline & $04 / 04 / 03 \mathrm{G}$ & 6.8 & -2.81 & -0.05 & 0.11 \\
\hline & $10 / 05 / 03 \mathrm{H}$ & 7.8 & -2.7 & -0.18 & -0.02 \\
\hline & $07 / 06 / 03 *{ }^{*} \mathrm{E}$ & 7.3 & -2.58 & -0.28 & -0.13 \\
\hline & $27 / 09 / 03 \mathrm{~F}$ & 8 & -2.06 & -0.73 & -0.58 \\
\hline mean & & 0.56 & -2.56 & -0.14 & 0.02 \\
\hline \multirow[t]{6}{*}{ OG-10 } & $22 / 11 / 02$ *B & 9.3 & -2.66 & 0.79 & 0.95 \\
\hline & $25 / 01 / 03{ }^{*} \mathrm{C}$ & 8.6 & -2.21 & -0.01 & 0.15 \\
\hline & 08/03/03 D & 8.3 & -2.63 & 0.06 & 0.21 \\
\hline & $04 / 04 / 03 \mathrm{G}$ & 8.1 & -2.76 & 0.05 & 0.21 \\
\hline & $10 / 05 / 03 \mathrm{H}$ & 7.8 & -2.7 & -0.18 & -0.02 \\
\hline & 07/06/03 *E & 8.7 & -2.42 & -0.3 & -0.14 \\
\hline mean & & 8.47 & -2.56 & 0.07 & 0.23 \\
\hline \multirow[t]{6}{*}{ OG-12 } & $25 / 01 / 03{ }^{*} \mathrm{C}$ & 4.7 & -2.07 & -2.22 & -2.06 \\
\hline & 08/03/03 *D & 5.5 & -1.91 & -0.81 & -0.65 \\
\hline & $04 / 04 / 03 \mathrm{G}$ & 5.2 & -2.84 & -1.26 & -1.1 \\
\hline & $10 / 05 / 03 \mathrm{H}$ & 6.4 & -2.94 & -1.07 & -0.91 \\
\hline & 07/06/03 * $\mathrm{E}$ & 6.2 & -2.81 & -0.97 & -0.81 \\
\hline & $27 / 09 / 03 \mathrm{~F}$ & 7 & -1.88 & -1.11 & -0.96 \\
\hline mean & & 5.83 & -2.41 & -1.24 & -1.08 \\
\hline \multirow[t]{8}{*}{ OG-14 } & $30 / 08 / 02{ }^{*} \mathrm{~A}$ & 8 & -2.84 & -0.24 & -0.09 \\
\hline & $22 / 11 / 02 * B$ & 8.4 & -2.59 & 0.64 & 0.79 \\
\hline & $25 / 01 / 03$ C & 8.4 & -2.34 & 0.30 & 0.46 \\
\hline & 08/03/03 *D & 9.3 & -2.74 & 0.67 & 0.82 \\
\hline & 04/04/03 G & 7.7 & -2.74 & 0.38 & 0.53 \\
\hline & $10 / 05 / 03 \mathrm{H}$ & 9.4 & -2.89 & 0.70 & 0.86 \\
\hline & 07/06/03 *E & 8.4 & -2.87 & 0.36 & 0.51 \\
\hline & $27 / 09 / 03 * F$ & 8.4 & -2.72 & -0.32 & -0.17 \\
\hline mean & & 8.42 & -2.72 & 0.31 & 0.46 \\
\hline
\end{tabular}

\section{Fauna analysis}

Table 6 provides a detailed list of the organisms found and the sampling points where they were collected. Species identification was not always possible owing to a scarcity of specimens (e.g., the single Hydridae specimen found) or specimen immaturity (e.g., the Lumbriculidae specimens, although they quite probably belong to the same species).

Ten major taxonomic groups were detected, comprising 53 taxa, among them: 15 Oligochaeta, 2 of them strictly subterranean and one endemic; a stygobiotic and another stygoxenic Turbellaria; the Bivalvia were represented by 2 species of Pisidium, a genus typical of superficial waters; copepods were very well represented with 14 Cyclopoida and 2 Harpacticoida species, at least 3 of these 16 species are new to science;
Table 4. Results of the Principal Component Analysis based on physico-chemical variables (upper panel), and coefficients for the linear combinations of variables making up PC's (lower panel). Significant values are in bold.

\begin{tabular}{|c|c|c|c|c|}
\hline $\mathrm{PC}$ & Eigenvalues & $\%$ Variation & \multicolumn{2}{|c|}{ Cumulated \% Variation } \\
\hline 1 & 3.16 & 22.6 & \multicolumn{2}{|c|}{22.6} \\
\hline 2 & 2.21 & 15.8 & \multicolumn{2}{|c|}{38.4} \\
\hline 3 & 1.97 & 14.1 & \multicolumn{2}{|c|}{52.5} \\
\hline \multicolumn{2}{|c|}{ Variable } & PC1 & PC2 & PC3 \\
\hline \multicolumn{2}{|c|}{$T^{\mathbf{a}}$} & 0.020 & -0.161 & 0.541 \\
\hline \multicolumn{2}{|l|}{$\mathrm{pH}$} & -0.208 & 0.497 & 0.090 \\
\hline \multicolumn{2}{|c|}{ Oxygen } & -0.049 & -0.300 & 0.192 \\
\hline \multicolumn{2}{|c|}{ Conduct. } & 0.253 & -0.165 & 0.361 \\
\hline \multicolumn{2}{|c|}{$\mathrm{CL}^{-}$} & -0.348 & -0.294 & -0.310 \\
\hline \multicolumn{2}{|c|}{ SO4= } & -0.391 & -0.214 & -0.127 \\
\hline \multicolumn{2}{|c|}{ NO3 $^{-}$} & -0.457 & -0.099 & 0.071 \\
\hline \multicolumn{2}{|c|}{$\mathrm{CO} 3 \mathrm{H}^{-}$} & -0.094 & -0.215 & -0.124 \\
\hline \multicolumn{2}{|l|}{$\mathrm{F}^{-}$} & 0.059 & -0.245 & 0.247 \\
\hline \multicolumn{2}{|c|}{ Formiate } & -0.064 & 0.510 & 0.287 \\
\hline \multicolumn{2}{|c|}{$\mathrm{Ca}^{++}$} & -0.003 & -0.042 & 0.097 \\
\hline \multicolumn{2}{|c|}{$\mathrm{Mg}^{++}$} & -0.362 & 0.006 & 0.393 \\
\hline \multicolumn{2}{|c|}{$\mathrm{K}^{+}$} & -0.263 & 0.315 & -0.174 \\
\hline \multicolumn{2}{|c|}{$\mathrm{Na}^{+}$} & -0.437 & -0.032 & 0.251 \\
\hline
\end{tabular}

Table 5. ANOSIM testing NMDS clusters of water samples based on physico-chemical data. Spring samples $(\mathrm{E}$ and $\mathrm{H})$ differ from summer samples (A and F) and autumn and winter samples (B and C). Letters $\mathrm{A}-\mathrm{H}$ refer to dates in Table 2. $\mathrm{W}=$ winter, $\mathrm{Sp}=$ spring, $A=$ autumn, $S=$ summer.

\begin{tabular}{lcc}
\hline Groups & R statistic & Significance level \% \\
\hline E. A (Sp-S) & 1.000 & 0.036 \\
E. B (Sp-A) & 0.909 & 0.005 \\
E. F (Sp-S) & 0.852 & 0.012 \\
C. E (W-Sp) & 0.824 & 0.02 \\
H. A (Sp-S) & 0.802 & 0.036 \\
C. F (W-S) & 0.796 & 0.012 \\
B. F (A-S) & 0.759 & 0.029 \\
G. E (Sp-Sp) & 0.750 & 0.002 \\
\hline
\end{tabular}

Overall $\mathrm{R}=0.498$, Significance level $=0.1 \%$

two species of Bathynellacea, both new to science.

Table 7 includes the contribution of the most common taxa to the total biodiversity of the cave and Table 8 the distribution of endemics and stygobionts per sampling point. Is there any global pattern of variation among the fauna over the whole sampling period? To answer this question the fauna matrix was converted into a similarity matrix using the Bray- Curtis similari- 


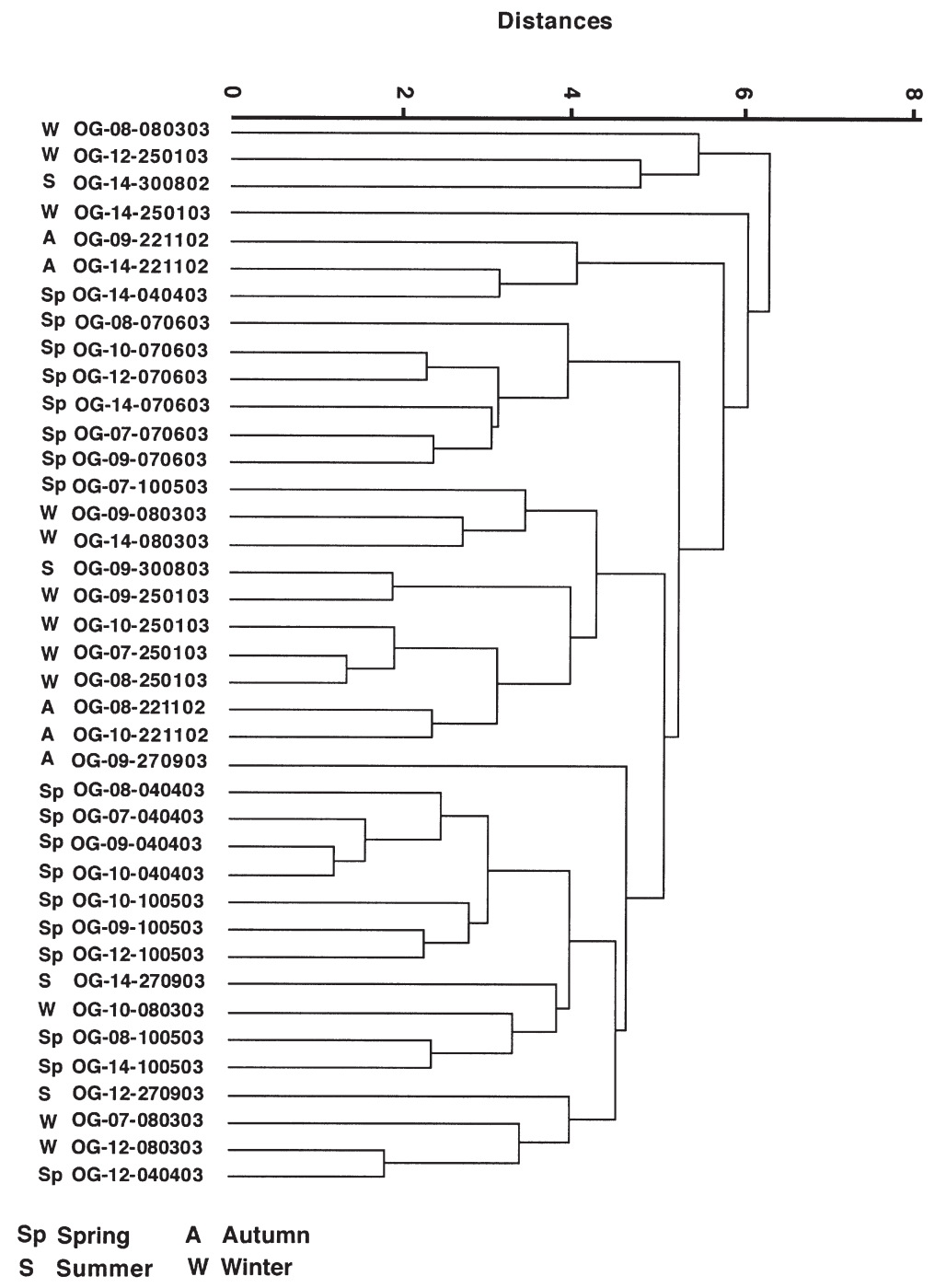

Fig. 4. Cluster based on chemical analysis of 39 samples of 6 sites collected in the four season of the year.

ty index and the samples ordered with NMDS. The best ordination of samples were by sampling point, all other ordinations -by season, kind of habitat and temporality- gave very mixed ordinations (Fig. 6).

To test the strength of samples ordered by sampling points we again used ANOSIM analysis. As Table 9 shows, some of the habitats were significantly different to one another.

Taking into account only those habitats for which we have chemical and faunistic identification, the greatest difference was between habitat 12 and $14(R=0.824$, $\mathrm{p}=0.002$ ). This difference is easily explained in terms of isolation. Habitat 14 is the closest to an entrance and habitat 12 is the most isolated habitat of the set. This could also be the reason for the difference between habitat 12 and habitat $9(\mathrm{R}=0.603, \mathrm{p}=0.005)$. Overlapped, but clearly different $(\mathrm{R}>0.5)$, are habitats 7,8 and 10 -located in the same subsection (2) of the cavethat were significantly different from habitats 9 and 14, in another subsection (4). These R statistics and those of habitat 12 suggest that the sampling points aggregate by cave subsection. However, other variables may 


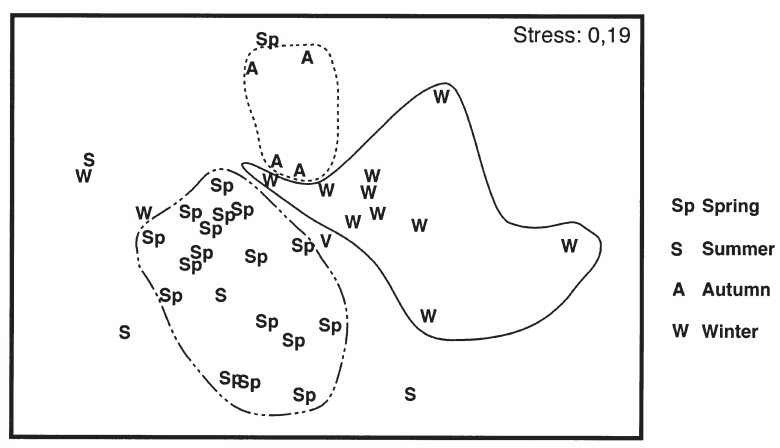

Fig. 5. NMDS ordination of 39 samples according to dates (four season) based in total chemical data.

come into play: the entrance habitats (9 and 14) are the most permanent, and the "Gours de la Hojas" habitats $(7,8,10$ and 15$)$ are temporary and very mineralized and the isolated habitat (12) always has water but very low mineralization due to its bed rock substrate. [SY2]

Agreement between habitat relationships based on faunistic and chemical data was tested with a BioEnv analysis. A similarity matrix based on the presence/absence of fauna (Table 6) and an environmental data matrix were used for this analysis (Table 2, samples with asterisks). From the environmental matrix, a dissimilarity matrix was calculated (using normalised Euclidean distances) for each of the possible combinations of the specified environmental variables (not necessarily all were used at once). The PRIMER BIOENV routine was used to calculate the agreement between the two matrices by rank correlating the matching elements of the two matrices. Table 10 shows the numerical code for the environmental variables and the correlation obtained for the different combinations of variables in decreasing order. The environmental variables and fauna were not highly correlated: the best combinations of variables explained a very small proportion of the variance. To see further into the cross relationship between environmental variables and faunistic diversity in habitats, another BioEnv analysis was carried out with the other variables associated with substrate shown in Table 11 and the total faunistic record per habitat (Table 6). No strong correlation was found among those variables and the fauna, the highest $(\mathrm{R}=0.3)$ being habitat position in cave.

\section{Discussion}

The composition of groundwater (Langmuir 1997) in karst systems is influenced by: (i) the chemistry of

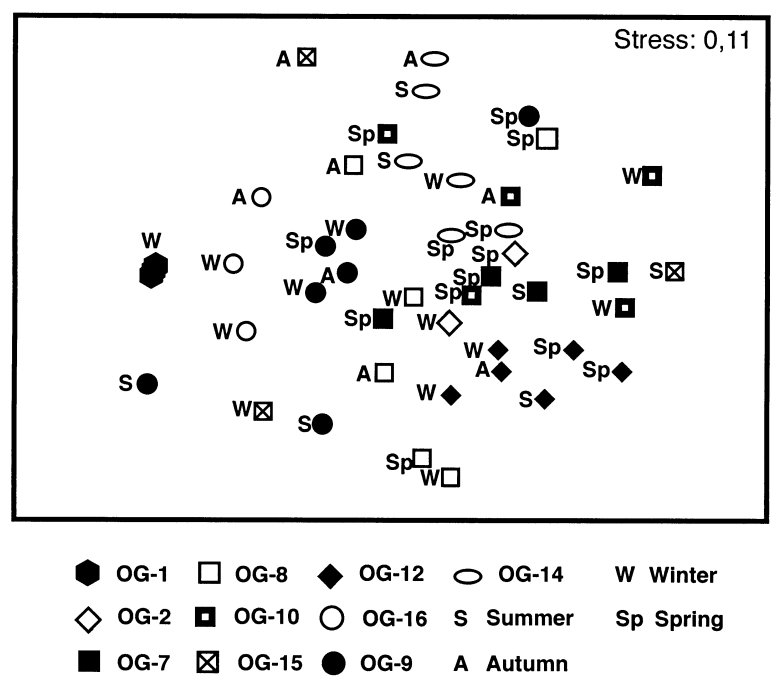

Fig. 6. NMDS ordination of sampling points by date according to taxa data.

precipitation (rainwater contains a few parts per million of dissolved solids and can contain dissolved organic carbon -about 0.5 to $1.5 \mathrm{mg} / \mathrm{l}-$, much of it in the form of formiate and acetate (Keene \& Galloway 1984); (ii) the leaching of salts accumulated between water infiltration events (a source of variable amounts of different ions, mainly $\mathrm{Cl}^{-} \mathrm{Na}^{-} \mathrm{SO}_{4}{ }^{-} \mathrm{K}$ ); (iii) the organic activity in the soil $\left(\mathrm{NO}_{3}\right.$, formiate, $\left.\mathrm{CO}_{2}\right)$; (iv) the petrological and mineralogical composition of the subsurface rocks $\left(\mathrm{HCO}_{3}{ }^{-} \mathrm{Ca}{ }^{-} \mathrm{Mg}\right)$; and (v) the hydrogeological properties of the rocks, which have a strong influence on the extent of water/rock interactions. The composition of the water at all the sampling points, and in particular the strong correlation between calcium and bicarbonate (Fig. 2-1), together indicate that the composition of the water in the studied sector of Ojo Guareña cave is controlled by the dissolution of the host rock after the filtration of rainwater. High $\mathrm{pCO}_{2}$ values in the soil water during cool periods cause the infiltration of small quantities of water with high concentrations. Soil $\mathrm{pCO}_{2}$ values are highest during the growing season because of plant respiration. A sudden storm after a dry summer period can, however, cause the opposite effect to that of the cold periods, i.e. the infiltration of high flows of water with few solutes but high concentrations of $\mathrm{CO}_{2}$ from the $\mathrm{CO}_{2}^{-}$enriched soil. The lowest $\mathrm{pCO}_{2}$ values in the sampled pools corresponded to samples collected in the spring rainy season. This was caused by regular rainfall and the subsequent progressive dissolution of the soil. In general, the sampled pools of the Ojo Guareña cave 
Table 6. Taxa found in Ojo Guareña 2002-2004 cave in 10 sampling sites. *stygobiotic; **stygophilic. Endemic taxa are in bold (Ind: indeterminate taxa).

\begin{tabular}{|c|c|}
\hline Taxa & Sampling sites \\
\hline Oligochaeta & $2 / 7 / 8 / 9 / 10 / 12 / 14 / 15$ \\
\hline 1.- Henlea sp. & 10 \\
\hline 2.- Aeolosomatidae (Ind.) & 10 \\
\hline 3.- Lumbriculidae (Ind.) & $2 / 7 / 8 / 9 / 10 / 14$ \\
\hline 4.- Limnodrilus hoffmeisteri Claparède, 1862 & 10 \\
\hline 5.- Potamothrix bavaricus (Öschmann, 1913) & 10 \\
\hline 6.- ${ }^{* \star}$ Rhyacodrilus falciformis Bretscher, 1901 & $2 / 8 / 10 / 12 / 14$ \\
\hline 7.- Achaeta sp. & $2 / 7 / 8 / 9 / 12 / 14$ \\
\hline 8.- Cernosvitoviella sp. & $2 / 7 / 8 / 10 / 14$ \\
\hline 9.- Enchytraeus sp. & 8 \\
\hline 10.- Fridericia sp. & $2 / 8 / 10 / 15 / 16$ \\
\hline 11.- Marionina cf. argentea (Michaelsen, 1889) & $2 / 7 / 8 / 10 / 14$ \\
\hline 12.- Nais communis Piguet, 1906 & $8 / 16$ \\
\hline 13.- **Pristinella jenkinae (Stephenson, 1931) & 2 \\
\hline 14.- *Trichodrilus tenuis Hrabe, 1960 & 14 \\
\hline 15.- *Phallodrilinae n.sp. & $8 / 9 / 10 / 15$ \\
\hline Turbellaria & $8 / 14$ \\
\hline 16.- *Prorhynchus stagnalis Schultze, 1851 & 8 \\
\hline 17.- Karchinorhynchus sp. & 14 \\
\hline Mollusca Gastropoda & $2 / 7$ \\
\hline 18.-Zospeum sp. & $2 / 7$ \\
\hline Mollusca Bivalvia & $7 / 8$ \\
\hline 19.-Pisidium casertanum (Poli, 1791) & 8 \\
\hline 20.- Pisidium personatum (Müller, 1774) & 7 \\
\hline Crustacea Copepoda Cyclopoida & $2 / 7 / 8 / 9 / 10 / 12 / 14 / 16$ \\
\hline 21.- Acanthocyclops robustus (Sars, 1863) & 10 \\
\hline 22. - *Acanthocyclops sp. & 10 \\
\hline 23.- Diacyclops bicuspidatus Claus, 1957 & $7 / 9$ \\
\hline 24.- Diacyclops b. odessanus (Schmankevitch, 1875) & 10 \\
\hline 25.- Diacyclops bisetosus (Rehberg, 1880) & $2 / 7 / 9 / 10 / 12$ \\
\hline 26. - Diacyclops nanus (Sars, 1862) & $2 / 10 / 12$ \\
\hline 27.- *Diacyclops sp. & $8 / / 9 / 12$ \\
\hline 28.- Diacyclops crassicaudis Sars, 1863 & 12 \\
\hline 29. - Diacyclops languidus Sars, 1863 & 7 \\
\hline 30.- Eucyclops serrulatus (Fischer, 1851) & 10 \\
\hline 31.- *Graeteriella (G.) unisetigera (Graeter, 1910) & 2 \\
\hline 32.- Megacyclops viridis viridis (Jurine 1920) & 10 \\
\hline 33.- Paracyclops fimbriatus (Fischer, 1853) & $2 / 7 / 10$ \\
\hline 34.- *Speocyclops infernus (Kiefer, 1930) & $9 / 14 / 16$ \\
\hline Crustacea Copepoda Harpacticoida & $10 / 14$ \\
\hline 35- Bryocamptus (B) minutus (Claus 1863 ) & 10 \\
\hline 36. - ${ }^{\text {Parastenocaris } \mathrm{sp} \text {. }}$ & 14 \\
\hline Crustacea Ostracoda & $2 / 7 / 8 / 9 / 10 / 12 / 14 / 15$ \\
\hline 37.- Candona candida (Müller, 1776) & $7 / 8 / 10$ \\
\hline 38.- Candona neglecta Sars, 1867 & $7 / 10 / 12 / 14 / 15$ \\
\hline 39.- Pseudocandona albicans (Brady, 1864) & 10 \\
\hline 40.- *Candoninae gen.sp. 1 & $7 / 9 / 12$ \\
\hline 41.- *Candoninae gen. sp2 & 9 \\
\hline 42.- Cypria sp. & $7 / 9 / 10$ \\
\hline 43.- Potamocypris sp. & $2 / 7 / 10 / 12 / 14$ \\
\hline Crustacea Isopoda & $2 / 9 / 10 / 12 / 14$ \\
\hline 44.- Stenasellus virei buchneri (Stammer, 1936) & $2 / 9 / 10 / 14$ \\
\hline 45.- *Proasellus ortizi Henry \& Magniez, 1992 & $2 / 12$ \\
\hline Crustacea Syncarida & $1 / 9 / 14 / 16$ \\
\hline 46.- *Vejdovskybathynella n.sp. & $1 / 9 / 16$ \\
\hline 47.- *Bathynellidae n.g. n.sp. & $9 / 14 / 16$ \\
\hline Tardigrada & $8 / 9 / 10 / 16$ \\
\hline 48.- Hypsibius pallidus Thulin, 1911 & 10 \\
\hline 49. - Itasquascon sp. & 8 \\
\hline 50.- Mixibius saracenus (Pilato, 1973) & 10 \\
\hline 51.- Macrobiotus hufelandi Schultze, 1834 & $9 / 16$ \\
\hline Acari & $7 / 8 / 14$ \\
\hline 52.- *Limnohalacaridae & $7 / 8 / 14$ \\
\hline Cnidaria & 10 \\
\hline 53.- Hydridae (Ind.) & 10 \\
\hline
\end{tabular}


Table 7. Summary of numbers of endemic and stygobiotic species per higher faunal groups.

\begin{tabular}{lcccc}
\hline Taxa & Total species & $\begin{array}{c}\text { Stygobiotic } \\
\text { species }\end{array}$ & Endemic species & New species \\
\hline Oligochaeta & 15 & 2 & 1 & 1 \\
Acari & 1 & 1 & 0 & 0 \\
Crustacea & 27 & 10 & 9 & 8 \\
Copepoda & 16 & 5 & 3 & 3 \\
Ostracoda & 7 & 1 & 2 & 2 \\
Isopoda & 2 & 2 & 2 & 1 \\
Amphipoda & 0 & 0 & 0 & 0 \\
Bathynellacea & 2 & 2 & 2 & 2 \\
TOTAL & 43 & 13 & 10 & 9 \\
\hline
\end{tabular}

Table 9. ANOSIM testing NMDS grouping of sampling sites based on faunistic data.

\begin{tabular}{lcc}
\hline Groups of sample sites & R Statistic & Signification level (\%) \\
\hline 12. 14 & 0.824 & 0.002 \\
9.12 & 0.603 & 0.005 \\
7.14 & 0.690 & 0.005 \\
10. 14 & 0.605 & 0.002 \\
9.14 & 0.593 & 0.003 \\
8. 12 & 0.574 & 0.002 \\
8. 14 & 0.524 & 0.004 \\
7. 9 & 0.513 & 0.006 \\
9.10 & 0.512 & 0.003 \\
\hline Overall $\mathrm{R}=0.518$, Significance level $=0.1 \%$ \\
\multicolumn{2}{l}{}
\end{tabular}

had bicarbonated, noncontaminated waters with only small chemical variations throughout the year. Although mean chemical composition varied little over the year, the $\mathrm{CO}_{2}$ concentration was affected by seasonal changes that followed a similar pattern at all sites. All winter samples showed carbonate oversaturation and a high $\mathrm{pCO}_{2}$.

Due to the isolation from the major climatic events occurring outside, or at least experiencing only the dampened effects of storms and changes in temperature, it might be thought that the chemical composition of these habitats would be similar over the year. However, the results show the major factor affecting water chemistry results to be the sampling date. Water composition changes over the year and is patently affected by external weather conditions. On the other hand, although the ANOSIM test points to a stronger similarity between samples within a sampling locality relative to other localities in the cave, it should be pointed out that all similarities are relative values, "relative to" something. The fauna recurrence per habitat and sampling date was not very high: the maximum number of taxa shared on two occasions in any one habitat was only 6 out of 14 (in OG-9). These numbers decline steeply when taking into account more than two sampling dates. Consequently, the fauna of these
Table 8. Distribution of stygobiotic and endemic species per habitat.

\begin{tabular}{lccc}
\hline Sampling Points & $\begin{array}{c}\text { Total number } \\
\text { of species }\end{array}$ & $\begin{array}{c}\text { Stygobiotic } \\
\text { species }\end{array}$ & $\begin{array}{c}\text { Endemic } \\
\text { species }\end{array}$ \\
\hline OG-1 Museo Cera & 1 & 1 & 1 \\
OG-2 Italianos & 15 & 3 & 2 \\
OG-7 GourHojas & 16 & 1 & 1 \\
OG-8 Gour Hojas & 15 & 4 & 2 \\
OG-9 Galeria Principal & 14 & 7 & 7 \\
OG-10 Gour Hojas & 28 & 3 & 3 \\
OG-12 Italianos & 10 & 2 & 3 \\
OG-14 Galeria Principal & 14 & 6 & 3 \\
OG-15 GourHojas & 3 & 1 & 1 \\
OG-16 Galería Principal & 6 & 3 & 2 \\
\hline TOTAL & 53 & 14 & 10 \\
\hline
\end{tabular}

Table 10. Results of the BioEnv analysis showing the correlations for different combinations of variables (see text). Variables: $1=$ $\mathrm{T}$; $2=\mathrm{pH} ; 3=$ Oxi; $4=$ Cond.; 5= CL- ; $6=\mathrm{SO}_{4}=; 7=\mathrm{NO}_{3}{ }^{-} ; 8=$ $\mathrm{CO}_{3} \mathrm{H}^{-} ; 9=\mathrm{F}^{-} ; 10=$ For $11=\mathrm{Ca}^{++} ; 12=\mathrm{Mg}^{++} ; 13=\mathrm{K}^{+} ; 14=\mathrm{Na}^{+}$.

\begin{tabular}{lll}
\hline Number of variables & Correlation $(\mathrm{R})$ & Selection of variables \\
\hline 6 & 0.258 & 1.2 .5 .8 .10 .11 \\
4 & 0.253 & 2.5 .10 .11 \\
5 & 0.247 & 2.3 .5 .10 .11 \\
5 & 0.245 & 2.4 .5 .10 .11 \\
5 & 0.244 & 2.5 .10 .11 .13 \\
3 & 0.242 & 5.10 .11 \\
5 & 0.236 & 1.4 .5 .10 .11 \\
4 & 0.234 & 2.5 .10 .13 \\
3 & 0.234 & 2.5 .11 \\
5 & 0.232 & 1.5 .10 .11 .13 \\
\hline
\end{tabular}

habitats cannot be described as stable. This raises a further question: do chemical and biological variables correlate with one another?

Two major kinds of habitats were apparent, depending on their chemical and biological composition: i) habitats with high or near-saturation carbonate concentrations (OG-8, OG-9, OG-10 and OG-14), mainly of a permanent nature (OG-9 and OG-14) or where water lasts much of the year (OG-8 and OG-10), with a muddy (OG-14 and OG-10) or mixed bottom (OG-8 and OG-9) and with a high organic content (these habitats harbour the highest diversity of fauna and the stygobite taxa); and ii) habitats that are temporary or permanent but with low mineralization and marked seasonal fluctuations. These were very poor in fauna. If the total fauna found in each habitat for all sampling occasions is compared (Table 6), the sites group together in the following fashion: OG-7 with OG-2, OG-10 with OG-2, OG-7 and OG-8 and OG-14 with OG-2, OG-7 and OG-10. The conclusion is that those variables do 
Table 11. Habitat variables associated to sampling sites. A: sampling points; $\mathrm{B}$ : type of habitat. $\mathrm{G}=$ gour and $\mathrm{P}=$ puddle; $\mathrm{C}$ : substrate. $\mathrm{R}=$ rock. $\mathrm{RS}=\mathrm{rock} / \mathrm{sand} . \mathrm{MS}=\mathrm{mud} / \mathrm{sand} . \mathrm{SS}=$ stones/sand and $\mathrm{RSS}=\mathrm{rock} / \mathrm{sand} / \mathrm{stones} ; \mathrm{D}$ : type of bottom. $\mathrm{C}=$ consolidated and $\mathrm{NC}=$ non-consolidated; $\mathrm{E}$ : water "type". $\mathrm{T}=$ temporary water (*high permanence of water). $\mathrm{P}=$ permanent water; $\mathrm{F}$ : Depth. $\mathrm{H}=$ high. $\mathrm{M}=$ medium and $\mathrm{L}=$ little; $\mathrm{G}$ : mineralization of the water. $\mathrm{A}=$ medium. $\mathrm{B}=$ high and $\mathrm{C}=$ low; $\mathrm{H}$ : Site. $1=$ sector one. $2=$ sector two. $3=$ sector three and $4=$ sector four.

\begin{tabular}{llcccccc}
\hline A & B & C & D & E & F & G & H \\
\hline OG-1 & G & RS & C & T & L & A & 1 \\
OG-2 & G & RS & C & T & L & A & 3 \\
OG-07 & P & MS & NC & T & L & B & 2 \\
OG-08 & P & SS & NC & T* $^{*}$ & L & B & 2 \\
OG-10 & P & MS & NC & T & M & B & 2 \\
OG-15 & G & RS & C & T & M & A & 2 \\
OG-12 & P & R & C & P & M & C & 3 \\
OG-16 & P & RSS & C & T & L & A & 4 \\
OG-09 & G & RS & C & P & H & B & 4 \\
OG-14 & P & RSS & NC & P & M & A & 4 \\
\hline
\end{tabular}

not correlate well with the fauna content of the habitats, as the BioEnv analysis showed before (Fig.6). In a similar fashion, there is no strong correlation with other variables and the fauna, such as with those variables implied in the topography. In conclusion, the yearly variation of the fauna does not affect their "faithfulness" to their preferred habitat.

OG-8, OG-9 and OG-14 have 4, 7 and 6 stygobiotic species respectively. OG-9 and OG-14 are permanent and have a similar oscillation in chemical species. OG8 is temporary, but has water almost all year round and together with OG-14 has an unconsolidated bottom with mud and organic matter and has been always oversaturated (or near equilibrium). OG-9 is a gour and is always in equilibrium. OG-10 was the most diverse with 28 taxa and 3 stygobionts, probably due to the fact that it receives water by constant dripping throughout the year, except during the driest years. OG-7 and OG-12 had only 1 and 2 stygobiotic taxa respectively, showed very low mineralization over the year, and had undersaturated carbonate concentrations.

However, Pipan et al. (2006) have studied 14 structural and physico-chemical factors to compare two types of habitats -trickles and pools filled with percolation water- in 6 caves from Slovenia. Main factors in trickles were the thickness of the cave ceiling and the concentrations of sodium, nitrate, and potassium ions. On the other hand, pools were affected by $\mathrm{pH}$, temperature, volume, conductivity and thickness of the cave ceiling.
In Ojo Guareña, the pools that are more stable in terms of water volume, and mineralization, that have a lower $\mathrm{pCO}_{2}$ and are carbonate oversaturated, harbor the greatest number of taxa and are those that can maintain strictly cave-dwelling species. Pools with lower levels of mineralization and greater water fluctuations have a lower diversity of fauna and cannot provide a suitable habitat for stygobiotic fauna. According to Pipan et al. (2006) some species of copepods recorded from pools had preference for high conductivity, high temperature and a dependence on water volume. They found that the abundance in pools was probably mostly a reflection of the amount of volume of pools collected, but the differences between drips may reflect the real differences between the leakage from the epikarst. In agreement with our present knowledge it appears that pools are subject to environmental fluctuations (specially drying) and that drips provide a less biased sample than pools (Pipan 2005). Stability is, consequently, more a property of the habitat than the cave system, and it is at that level that further research should be continued.

Subterranean ecosystem have long been considered as extreme environments inhabitet by only a few specialized species. This paradigm is now being revised, as many studies show that this environment harbors diverse animal communities (mainly invertebrates) across different space and time scales (Gibert \& Deharveng 2002). It is now accepted the great faunistic diversity of these habitats taken individually and as an assemblage in a karstic area (Pipan 2005). Pipan, 2005 has found between 8 and 15 species of stygobiotic copepods in each one of the caves she studied, showing that the copepods diversity in the epikarst may overwhelm the diversity of other stygobionts. Aditionally, Pipan et al. (2006) have found 37 species of copepods, 27 of them stygobionts, in 6 caves in Slovenia. Each individual cave could hold between 5 and 14 species in trickles and 7 and 13 species in pools. We have found 16 species of copepods in a single cave, 5 of them stygobionts and at least 3 endemic. In conclussion, the easiest way to sample the epikarst fauna of a cave is to sample pools, unfortunately, pool sampling is far from an unbiased sample of the epikarst.

Although the sector studied is a small part of the cave system, there were 14 properly stygobiotic species from a total of 53 taxa belonging to 10 higher faunal groups (Table 6 and 8). The statement "it appears that groundwater biotopes contain highly diverse faunas with high levels of local and regional endemism" (Marmonier et al. 1993), has been confirmed in this preliminar study. We have 9 endemic taxa within the 
14 stygobiotic identified species and it is sure that when more deeply studied the number will raise. As a matter of fact, later samplings in other epikarstic areas near to the present cave system have produced some new species to Science (Camacho 2003, 2005a, $2005 \mathrm{~b}$ ) and raised the number of stygobios in the area. Whether or not this proportion is a characteristic of the cave should be investigated. Finally, in spite of the fact that much research has been carried out these last 30 years and our knowledge of karst system properties has increased considerably, a global and conceptual model that could describe and explain the spatial and temporal distribution of karst water organisms is still lacking (Gibert et al. 1994).

\section{Acknowledgements}

The authors thank R. García, M. I. Ruiz and M. A. Vallejo for the performing the chemical analysis. C. Puch helped in the sampling trips and redrew the topography of the cave section studied in this work. S. González de Uzqueta, A. de Juan, F. Lázaro and J. Robador assisted in field work. The following people assisted with the identification of taxa: R. Araujo, B. Arconada, N. Guil, D. Jaume, P. Marmonier, C. Noreña, P. Rodriguez, F. Stoch. Sarah Young corrected the English version of the manuscript. Projects PASCALIS EVK2-CT-2001-00121; Convenio Junta de Castilla y León-CSIC (2002-2004) and BTE2002-04492-C02-02.

\section{References}

Apostolov A. \& Pandourski I. 2004. - Crustacés des eaux souterraines karstiques des montagnes de Vitocha et de Golo bardo (Bulagrie Occidentale) : composition taxonomique, caracteristiques generale et repartition spatiale dans le karst. Hist. Nat. Bulgarica, $16,45-57$.

Brancelj A. 2002. - Microdistribution and high diversity of copepoda (Crustacea) in a small cave in central Slovenia. Hydrobiologia, 447, 59-72.

Brancelj A. \& Pipan T. 2004. - Diversity of Copepoda (Crustacea) in the unsaturated zone of karstic caves in Slovenia. Pages 323332 in Balkan Biodiversity: Pattern and Process in the European Hotspot. Griffiths H.I., Krystufek B. \& Reed J.M. (eds). Kluwer Academic, Dordrecht, London.

Brancelj A. \& Culver D.C. 2004. - Epikarstic communities. In Encyclopedia of Caves. Culver D.C. \& White W.B (eds). Academic/Elsevier Press, San Diego.

Camacho A.I. 2003. - Four new species of the groundwater crustaceans (Syncarida, Bathynellacea, Parabathynellidae) endemic to the Iberian Peninsula (Portugal and Spain). J. Nat. Hist., 37, 28852907.

Camacho A.I. 2005a. - Expanding the taxonomic conundrum: three new species of groundwater crustaceans (Syncarida, Bathynellacea, Parabathynellidae) endemic to the Iberian Peninsula. J. Nat. Hist., 39, 1819-1838.

Camacho A.I. 2005b. - One more piece on the genus puzzle: a new species of Iberobathynella (Syncarida, Bathynellacea, Parabathynellidae) in the Iberian Peninsula. Graellsia, 61, 123-133.

Chapman M.G. \& Underwood, A.J. 1999. - Ecological patterns in multivariate assemblages: information and interpretation of negative values in Anosim tests. Mar. Ecol. Prog. Series, 80, 257-265.

Clarke K.R. \& Gorley R.N. 2001. - "PRIMER v5: User Manual/Tutorial". PRIMER-E: Plymouth.

Clarke K.R. \& Green R.H. 1988. - Statistical design and analysis for a "biological effects" study. Mar. Ecol. Prog. Series, 46, 213-226. Clarke K.R. \& Warwick R.M. 2001. - Change in marine communities: An approach to statistical analysis and interpretation, 2nd edition PRIMER-E: Plymouth.

Culver D.C. \& Holsinger J.R. 1992. - How many species of troglobites are there? N.S.S., Bulletin, 54, 79-80.

Culver D.C., Master L.L., Christman M.C. \& Hobbs H.H. 2000. Obligate cave fauna of the 48 contiguous United States. Conserv. Biol, 14, 386-401.

Culver D.C. \& Sket B. 2000. - Hotspots of subterranean biodiversity in caves and wells. J. Cave Karst Stud., 62, 11-17.

Culver D.C., Christman M.C., Elliot W.R., Hobbs III H.H. \& Reddell J. 2003. - The North American obligate cave fauna: regional patterns. Biodiv. Conserv., 12, 441-468.

Culver D.C., Christman M.C., Sket B. \& Trontelj P. 2004. - Sampling adecuacy in an extreme environment: species richness patterns in Slovenian caves. Biodiv. Conserv., 13, 1209-1229.

Deharveng L. \& Bedos A. 2000. - The cave fauna of Southeast Asia. Origin, evolution and ecology. Pages 603-633 in Subterranean Ecosystem. Ecosystem of the World vol. 30. Wilkens H., Culver D.C. \& Humphries W.F. (eds). Elsevier, Amsterdan.

Fairchild I.J., Smith C.L., Baker A., Fuller L., Spötl C., Mattey D. , McDermott F. \& E.I.M.F. 2006. - Modification and preservation of environmental signals in speleothems. Earth-Science Rev., 75, $105-153$.

Jefferson G.T., Chapman P., Carter J. \& Proudlove G. 2004. - The invertebrate fauna of the Ogof Ffynnon Ddu cave system, Powys, South Wales, UK. Cave Karst Sci., 31(2), 63-74.

G.E.E., 1986. - Complejo kárstico de Ojo Guareña. Kaite 4-5 Monogr-fico. Ed. Excm. Diputación Provincial de Burgos, Burgos.

Gibert J. 1986. - Ecologie d'un système karstique jurassien. Hydrogéologie, dérive animale, transit de matières, dynamique de la population de Niphargus (Crustacé Amphipode). Mem. Biospéol., 13, 1-379.

Gibert J., Stanford J.A., Dole-Olivier M.-J. \& Ward J.V. 1994. - Basic attributes of groundwater Ecosystems and Prospects for research. Pages 7-40 in Groundwater Ecology, Aquatic Biology series. Gibert J., Danielopol D.L. \& Stanford J.A. (eds). Academic Press, London.

Gibert J., Vervier Ph., Malard F., Laurent R. \& Reygrobellet L.L. 1994. - Dynamics of communities and ecology of karst ecosystems: example of three karsts in Eastern and Southern France. Pages 425-450 in Groundwater Ecology, Aquatic Biology series. Gibert J., Danielopol D.L. \& Stanford J.A. (eds). Academic Press, London.

Gibert J. \& Deharveng L. 2002. - Subterranean Ecosystem: A truncated Funcional Biodiversity. BioScience, 52, 473-481.

Graening G.O., Slay M.E. \& Tinkle K.K. 2003. - Subterranean biodiversity of Arkansas, part 1: bioinventory and bioassessment of caves in the Sylamore Ranger District, Ozark National Forest, Arkansas. J. Arkansas Acad. Sci., 57, 44-58.

Humphreys W.F. 2002. - The subterranean fauna of Barrow Island, northwestern Australia, and its environment. Mem. Biospeol., 28, 107-127.

Jones W.K. 2003. - Introduction to epikarst. Pages 3-7 in Epikarst. Proceedings of the Symposium held October 1 through 4, 2003, Sheperdstown, West Virginia, USA.

Jones W.K., Culver D.C. \& Herman J.S. (eds). Karst waters Institure Special Publication 9, Charles Town, W. VA.

Jones W.K., Culver D.C. \& Herman J.S. (eds) 2004. - Epikarst. Proceedings of the Symposium held October 1 through 4, 2003, Sheperdstown, West Virginia, USA. Karst Waters Institute Special Publ. 9, Charles Town, W.Va., 160 p.

Keene W.C. \& Galloway J.N. 1984. - Organic acidity in precipitation of North America. Atmos. Environ., 18, 2491-2497. 
Kniss V.A. 2004. - Zoogeographical análisis and specificity of subterranean fauna in the territory of the former USSR. Zool. Zh., 83 , 615-620.

Know S. \& Culver D.C. 2001. - Gaps in sampling cave fauna. Mem. Biospeol., 28, 129-136.

Langmuir D. 1997. - Aqueous Environmental Geochemistry. Prentice-Hall, Inc. $600 \mathrm{pp}$

Malard, F. \& Gibert J. 1997. Stygobiotic fauna of the North Montpelliérains karsts with special emphasis on the Lez karst system. From First Annual Top Ten List of Endangered Karst Ecosystem. Karst Waters Institute Special Publications 3, Charles Town W. VA.

Marmonier P., Vervier P, GibertJ. \& Dole-Olivier J.-M. 1993. - Biodiversity in ground waters. Trends Ecol. Evol., 8, 392-395.

Moldovan O.T. 2002. - Research on groundwater fauna in northwestern Romania. Stud. Univers. Babes-Bolyai Biol., 47, 15-32.

Negrea S. \& Boitan V. 2001. - An ecological and biogeographycal overview of the terrestrial and aquatic subterranean environments from Romania. Trav. Mus. Nat Hist. Natur. "Grigore Antipa”, 43, 367-424.

Pesce G.L., Ciccarese N. \& Honorato R. 2004. - Ricerche biologische nell'acquifero del complexo carsico di Badisco (Otranto). Thal. Salentina, 27, 91-97.

Pipan T. 2003. - Ecology of copepods (Crustacea: Copepoda) in percolation water of the selected karst caves. Doctoral Dissertation, University of Ljubljana, Ljubljana, $130 \mathrm{pp}$.

Pipan T. 2004. - Ecological and Microgeographical study of an epikarstic fauna in USA. Ljubljana, Acta Carsol., 33, 269-275.

Pipan T. 2005. - Epikarst- A promissing habitat. Copepod fauna, its diversity and ecology: a case study from Slovenia (Europe). Carsologica, 5, 1-101.

Pipan T. \& Brancelj A. 2001. - Ratio of copepods (Crustacea: Copepoda) in fauna of percolation water in six karst caves in Slovenia. Ljubljana, Acta Carsol., 30, 257-265.

Pipan T. \& Brancelj A. 2003. - The fauna of epikarst: Copepoda (Crustacea) in percolation water of karst caves in Slovenia. Ann. Series Hist. Nat. (Koper), 13, 223-228.

Pipan T. \& Brancelj A. 2004a. - Diversity and peculiarity of epikarst fauna: case study from six caves in Slovenia (Europe). Pages 119 126 in Epikarst. Proceedings of the Symposium held October 1 through 4, 2003, Sheperdstown, West Virginia, USA. Jones W.K., Culver D.C. \& Herman J.S. (eds). Karst waters Institure Special Publication 9. Charles Town, W. VA.
Pipan T. \& Brancelj A. 2004b. - Distribution patterns of copepods (Crustacea: Copepoda) in percolation waters of the Postojnska Jama Cave (Slovenia). Zool. Stud., 43, 206-210.

Pipan T. \& Culver D.C. 2005. - Estimating biodiversity in the epikarstic zone of a West Virginia cave. J. Cave Karst Stud., 67, 103109.

Pipan T., Blejec A. \& Brancelj A. 2006. - Multivariate analysis of copepod assemblages in epikarstic waters of some Slovenian caves. Hydrobiologia, 559, 213-223.

Plummer L.N., Parkhurst D.L., Fleming G.W. \& Dunkle S.A. 1988. - PHRQPITZ, a computer program incorporating Pitzer's equations for calculation of geochemical reactions in brines. US Geol. Surv. Water-Resources Inves. Report, 88, 41-53.

Proudlove G.S. 2001. - Subterranean Biodiversity in the British Isles. Pages 56-58 in Mapping Subterranean Biodiversity. Culver D.C., Deharveng L., Gibert J. \& Sasowsky I. D. (eds). Karst Waters Institute Special Publications 6. Charles Town, W. VA.

Puch C. 1998. - Grandes Cuevas y Simas de España. Espeleo Club de Gracia, Barcelona, 816 pp.

Reid J.V. 2004. - New records and new species of the genus Diacyclops (Crustacea: Copepoda) from subterranean habitats in southern Indiana, USA. Jeffersonia, 12, 1-65.

Sánchez-Moral S., Cuezva S., Lario J. \& Taborda-Duarte M. 2006. Hydrochemistry of karstic waters in a low-energy cave (Castañar de Ibor, Spain). Pages 339-347. in Karst, cambio climático y aguas subterráneas. Durán,J.J., Andreo B. y Carrasco F. (eds.). Publicaciones del Instituto Geológico y Minero de España. Madrid. Serie: Hidrogeología y Aguas Subterráneas, $\mathrm{n}^{\circ} 18$.

Schneider K. \& Culver D.C. 2004. - Estimating subterranean species richness using intensive sampling and rarefaction curves in a high density cave region in West Virginia. J. Cave Karst Stud., 66, 3945 .

Sket B. 1999. - High biodiversity in hypogean wwaters and its endangerment- the situation in Slovenia, the Dinaric Karst, and Europe. Crustaceana, 72, 767-779.

Sket B., Trontelj P. \& Zagar C. 2004a. - Speleobiological characterization of the epikarst and its hydrological neighborhood: its role in dispersión of biota, its ecology and vulnerability. Pages 104113 in Epikarst. Proceedings of the Symposium held October 1 through 4, 2003, Sheperdstown, West Virginia, USA. Jones W.K., Culver D.C. \& Herman J.S. (eds). Karst waters Institure Special Publication 9. Charles Town, W. VA. 